\title{
Mobilya- Biçim- Tercih
}

\author{
Yaprak Özel ${ }^{1 *}$, Zerrin Funda Ürük ${ }^{2}$ \\ 1* İstanbul Gelişim Üniversitesi, Güzel Sanatlar Fakültesi, İç Mimarlık Bölümü, İstanbul, Türkiye (ORCID: 0000-0002-6439-4817) \\ , yozel@gelisim.edu.tr \\ 2 İstanbul Gelişim Üniversitesi, Güzel Sanatlar Fakültesi, İç Mimarlık ve Çevre Tasarımı Bölümü, İstanbul, Türkiye (ORCID: 0000-0002-3994-5883), \\ zfuruk@gelisim.edu.tr
}

(İlk Geliş Tarihi 1 Şubat 2021 ve Kabul Tarihi 9 Nisan 2021)

(DOI: 10.31590 /ejosat.888726)

ATIF/REFERENCE: Özel, Y. \& Ürük, Z. F. (2021). Mobilya- Biçim- Tercih. Avrupa Bilim ve Teknoloji Dergisi, (21), 589-600.

\section{Öz}

Kullanıcı, tasarımcı ve mekân arasındaki iletişimi ve etkileşimi sağlayan öğeler mobilyalardır. Profesyonel ellerce tasarlanıp üretilen, kullanıcısına özel mobilyalar olabildiği gibi, aile içinde nesilden nesile aktarılan simgesel işlevi hizmet işlevinin önüne geçmiş veya bir firmanın seri olarak ürettiği bir koleksiyonunun parçasıda olabilmektedir. Bu özellikleri ile aslında mobilya kullanıldı̆̆ içinde bir nevi iletişim ve etkileşim aracına dönüşmektedir. Mekâna işlev vermekte, mekân içi sirkülasyonu yönlendirmekte ve biçimlendirmektedir. Kullanıcısının sosyo-kültürel yapısını, beğeni ve tercihlerini ve hatta kullanıcının ekonomik düzeyi hakkında da bilgi sunmaktadır. Geçmişinden bugüne mobilyalar; bir iletişim ve etkileşim aracı olma özelliği taşımış ve statü göstergesi olmuştur. Mobilya tarihine bakıldığında bir mobilya sahibi olabilmek ancak bir statü ile mümkün olduğu için bir bakıma halen bir statü göstergesi olma özelliğini taşımasına neden olmaktadır. Bir diğer yandan içinde bulunulan dönemin sosyo-kültürel motivasyonları, moda gibi faktörler sonucu bir dizi güdülenmiş gereksinimin ortaya çıkardığı eşyalara bir düzen verme endişesi de daha çok mobilyaya sahip olmayı tetiklemekte ve yine statü göstergesi olarak mobilya tercih edilmektedir. Günümüzde de mobilyalar arası hiyerarşik bir düzen devam etmektedir.

Mobilya tasarım süreci ilk aşamasından itibaren çeşitli etkenler ile oluşmakta biçimlenmekte ve hayata geçmektedir. Bir mobilyanın tasarlanması aşamalarında daha ilk fikrin oluşturulmasından, kullanımına kadar ki süreci etkileyen ve belirleyen pek çok etken ve etki vardır. Bu etken ve etkilerin birçoğu birbiri ile iç içe geçmiş etkileşimlerdir. Alternatif tasarım çözümleri, bu çözümleri etkileyen mobilyanın kullanılacağı mekânın etkileri, mobilyanın o mekân içindeki konumu ve hizmet işlevi, malzeme alternatifleri, renk ve dokusal farklılıklar, antropometrik çerçevede kullanıcı ve mekâna bağlı farklılaşabilen boyutlar, tasarımcı kimliği, kullanıcısının beğeni ve tercihleri, sosyo-kültürel yapısı (mobilyanın estetik ve simgesel işlevi) ve ekonomik düzeyi, mobilyadan beklenen ek işlevlerin olup olmadığı ve histiflenebilme ve depolanması gibi özel şartlar gibi etken ve etkileri düşünürek, tasarımcı tasarlama ve sonrasında üretilmesi işlemlerini gerçekleştirir. Bu kararlar aşamasında biçim yeri gelince yeniden de oluşturulmaktadır. Son tasarım kullanıcı ve tasarımcı tarafından onaylandıktan sonra üretime geçmektedir. Çıkan ürün mekân içinde konumunu aldıktan ve mekân içindeki diğer öğelerle ilişkilendirildikten sonrasında da taşıdığı özellikler çerçevesinde hem mekânı hem de kendini tanımlamaktadır.

Anahtar Kelimeler: Mobilya, İç Mimari Tasarım, Yapım Teknolojileri.

\section{Furniture-Form- Preference}

\begin{abstract}
Furniture is the elements that provide the communication and interaction between the user, designer and the space. There are also furniture that is designed and produced professionally, as well as user-specific furniture, passed down from generation to generation within the family. Its symbolic function takes precedence over the service function or it can be a part of a company's serially produced collection. With these features, furniture turns into a communication and interaction tool in the space. It functions the space, directs
\end{abstract}

\footnotetext{
*Sorumlu Yazar: yozel@gelisim.edu.tr
} 
and shapes the circulation inside the space. It presents the socio-cultural structure, taste and preferences and economic level of its user. Furniture from past to present; it has become a communication and interaction tool and status indicator. Considering the history of furniture, acquiring a furniture is only possible by having a status. For this reason, it still has the characteristic of being a status indicator. On the other hand, the concern of giving an order to the items brought about by a series of motivated needs as a result of factors such as socio-cultural motivations and fashion of the current period triggers more furniture and furniture is preferred as a sign of saturation. Today, a hierarchical order between furniture continues.

The furniture design process is formed, shaped and implemented with various factors from the first stage. There are many factors and effects that affect and determine the process from the creation of the first idea to its use in the stages of a furniture design. Many of these factors and effects are intertwined interactions with each other. Alternative design solutions, the effects of the place where the furniture affecting these solutions will be used, the location of the furniture in that space and the service function, material alternatives, color and textural differences, dimensions that can differ depending on the user and space in an anthropometric framework, the designer identity, the user's tastes and preferences, the socio-cultural structure (the aesthetic and symbolic function of furniture) and its economic level, whether there are additional functions expected from the furniture and special conditions, such as stacking and storage, the designer do the design by making decisions and then start the production. In these decisions, the form is recreated and re-created. After the final design is approved by the user and the designer, it goes into production. After the product takes its position in the space and is associated with other elements in the space, it defines both the space and itself within the framework of its features.

Keywords: Furniture, Interior Design, Manufacturing Technologies.

\section{Giriş}

Günümüzde mobilyalar toplumsal düzeyin ortaya konulmasından, kullanıcının sanatsal eğilimlerinin yansıtılmasına kadar talep ve ihtiyaçlar çerçevesinde belirlenen son derece geniş ve karmaşık bir yelpaze içermektedir. Geçmişin emek-yoğun teknikleriyle üretilebilen ve ancak belli kesimlerce sahip olunabilen, hiyerarşi, lüks ve statü göstergesi olan mobilyalar, standart olmamakla birlikte, kalitesi ve üretim süresi ustasının el becerisine bağlı olarak değişkenlik göstermekteydi. Teknolojik gelişmeler ve güncel üretim teknikleri sayesinde sayı, süre ve biçimsel farklılıklar gibi imkânlarla taleplere cevap verebilir hale gelmiştir.

Mobilya kelime anlamı itibariyle hareket içermektedir. Ancak tarihinden bugüne birçok mobilya mekân ile birlikte çözülebilmekte sabit veya yarı hareketli olabilmekte veya bir noktadan çevresi ile bağımlı olarak da çözümlenmekte ve kullanılmaktadır.

Mobilya döşeme eşyası, mefruşat, çeşitli fonksiyonlara cevap vermek amaciyla üretilmiş hareketli şey, eşyalar gibi pek çok farklı tanımlamaya sahiptir. Kimi zaman bir döneme, üsluba veya anlayışa simge olarak kendi başına adeta bir heykel haline gelmiş bir tasarım, kimi zaman mekânı oluşturan, ona işlev veren ve içindeki yaşam akışını düzenleyen-yönlendirenbiçimlendiren birimler olmuştur. Kimi zamansa, tekil ve başlica tasarım öğesi olarak ne bir mekâna ait ne bir mekânın parçası ama kullanıcısı veya tasarımcısı için üretildiği malzeme ve biçimlenişi ile bir iletişim aracı olarak karşımıza çıkmaktadır.

$\mathrm{Bu}$ çalışmada mobilya olgusu, tasarlanması, uygulanması yani hayata geçirilmesi ve seçim süreçlerini etkileyen, yönlendiren etkenler ortaya konarak, mobilyanın işlev, biçimleniş ve tercih edilme ilişkileri açıklanmaktadır.

Tanımlanmasından, tasarımına, yapımından seçimine, kullanılması ve işlevini yitirme aşamasına kadar ki aşamalar karmaşık bir etkileşim ağı oluşturmaktadır. Bu aşamada bazı temel değerler ortaya konarak bu karmaşı sürecin kolaylaştırılması gerekliliği doğmaktadır ve bu sayede özgün eserlerin ortaya konmasında yardımcı olması hedeflenmektedir.

\section{Materyal ve Metot}

\subsection{Mobilya Olgusu ve Açılımı}

Mobilyanın dönemsel olarak tarihine bakıldığında, göçebe kültürün olduğu dönemlerde, sandık ve benzeri taşınabilir depolama elemanları gibi az sayıda mobilyalar üretilmiş olsa dahi asıl başlangıç aşaması olarak yerleşik hayata geçiş ile ilk olarak konutlarda görülmektedir. İlk yerleşimlerde zemin ve duvarlarda elde edilen yükselti ve girintiler o dönem için çeşitli ihtiyaçları karşılamada yeterli görülmektedir. Halk tarafından dinlenme ve diğer ihtiyaçları için kullandıkları basit tabure işlevi gören yükseltiler veya saman yığınları yeterli kabul edilmektedir. $\mathrm{Bu}$ aşamada gerçek bir mobilya sahibi olabilmek için belirli bir statü sahibi olma gerekliliği görülmektedir. Ancak bir marangoz tarafından emek-yoğun bir şekilde çalışarak ustaca dönemin üslubuna göre üretilmiş bir mobilyaya sahip olmak için halktan farklı bir görev üstenmiş olunması asil, soylu olmak veya ülke yönetiminde yer almak gerekliliği vardı.

Tarihinin ilk dönemlerindeki değerini; günümüzde herkes tarafından ulaşılabilir olması nedeniyle kaybetmiş olsa da insanın yetersiz kaldığı durumlarda bedenin uzantısı veya tamamlayıcısı olarak görevler üstlenerek hayatı kolaylaştırırken insana güzellikte sunan mobilyalar, mekânlarda yerlerini almaktadırlar.

Mobilyanın; hayata geçme, var olma ve üç boyutu ile ortaya çıkma aşamasının ilk adımı, tasarımının zihninde belirecek imajı oluştururuken karşılaşacağı kısıtlar ve özgürlükler nelerdir ve hangi faktörler etken oluşturmaktadır, işlev mi biçimi, biçim mi işlevi oluşturmada etkin olacaktır soruları çözümlenmeye çalışılmıştır.

$\mathrm{Bu}$ çözümleme ile öncelikle mobilyaların işlev şemalarının oluşturulmasını, işlev sınıflandırılmasını yapılmasını ve sonuç olarak biçimin oluşturulmasındaki etkinliklerin ortaya konması ile açıklanmaktadır. 


\section{2. İşlev- Eylem ve Tasarım Aşamasındaki Etkinliği}

$\mathrm{Bu}$ aşama da mobilyanın biçimlendirilmesinde çeşitli sinıflandırılmaların yapılması hem tercihlerin doğru yönlendirilmesi açısından hem de tasarımcının oluşturacağ biçime yol gösterici olması için gerekli görülmektedir. Mobilyanın yapım aşaması kararlarının alınması sürecinde veya tasarım aşamasında ana belirleyici faktör olarak eylem sınıflandırması ve işlev gelmektedir.

İnsanın eylemlerinde destekleyici bir rol üstlenen mobilyalar; oturma, dinlenme, yatma, depolama, koruma, düzenleme, çalışma, hizmet-servis gibi eylem ve gereksinim doyumlarının karşılanmasında yaşantıyı bir yandan kolaylaştırırken bir yandan da yönlendiren güdüleyen, belirleyici ve saptırıcı bir dizi faktörler yığını olarak karşımıza çıkmaktadır.

Birçok farklı eyleme cevap vermesi karşılaması beklenen mobilyalar, bazen bir eylemden diğerine geçiş aşamasında dahi bir işlev üstlenebilmektedir. Bu nedenle insanın statik (durağan) ve dinamik (hareketli) duruş biçimleri bu sınıflandırma için yetersiz kalmaktadır. Çünkü insan statik duruş biçimlerinde farklı eylemleri yerine getirebileceği gibi statik ile dinamik duruş biçimlerine geçiş durumu da bu hareket biçimleri ile yapılacak bir sınıflandırma açısından karşılıksız kalmaktadır. İnsanın "yaşamsal eylemlerine" göre bu sınıflandırma yapılmalı ve şu başlıklar altında mobilyaların ana işlevleri gruplanmalıdır.

- Çalışma

- Beslenme

- Temizlik ve bakım

- Dinlenme, eğlenme ve oyalanma

- Uyuma

- Birleşik eylemler

$\mathrm{Bu}$ sınıflandırmaya bağlı olarak mobilyanın tasarlanması veya tercih edilmesi sürecinde, birinci aşamada çözümlenmesi gereken "ne hizmeti verecek" sorusunun yanıtını oluşturan işlev kelimesini kısaca tanımlamak gerekirse; nesnenin kendisinden beklenileni yerine getirmesidir. Mobilya biçimlendirilmesinde ve tercihlerinde işlev; pratik, esteik ve simgesel olarak üç ana başlık şeklinde karşımıza çıkmaktadır.

Pratik İşlev; olarak tanımlanan ana hizmet işlevi, Şekil 1 ve 2'de görüleceği gibi mobilyanın asıl tasarlanma ve kullanılma amacıdır ve mobilyanın ne işe yarayacağının cevabını oluşturmaktadır. İnsanın antropometrik ölçüleri çerçevesinde bir oturma elemanın ana işlevi kullanıcının yorgunluğunu giderecek şekilde biçimlendirilmelidir.

İşlev başlığı mobilya tasarımı ve tercihi bakımından sadece hizmet eylemi ile değerlendirmek yeterli olmayacaktır. Bir mobilyanın öncelikle tercih edilmesi için kullanıcısının beğenisini kazanmalıdır. Tercih ve beğenilerin devreye girdiği bu durum mobilyanın estetik işlevi olarak adlandırılmaktadır. Şekil 3 ve 4'de görüldüğü üzere göze güzel gözüken, malzemesi ve rengi ile aynı hizmeti sunmak için üretilmiş, diğerlerinden o ürünü ayrıan ve kişiler açısından farklılık gösteren bu işlev başlığıdır. Öncelikli tercih aşamasında ana işlev (pratik işlev) gelirken ikinci sırada beğeniye bağlı estetik işlev devreye girmektedir.

Mobilyanın tercihi aşamasında kullanıcısına sunabileceği veya tasarımı aşamasında üstlenebileceği bir diğer işlev başlığ ise simgesel işlevdir. Her mobilyanın bu özelliği taşıması gibi bir gerekliliği yoktur. Ancak kullanıcısı ile kuracağı bağ kuvvetlendirmektedir. Çoğu zaman bu bağ ile mobilya alternatiflerine göre daha pahalı olsa veya belirlenen bütçeyi aşsa dahi tercih edilmesini sağlamaktadır. $\mathrm{Bu}$ işlevin yüklü olduğu mobilyalarda; görsel yolla iletilen anlık, psikolojik ve sosyal etkiler birlikte sunulmaktadır.

Bu aşamada mobilyanın ve diğer tüm objelerin üstlendikleri iletişim işlevi göz ard1 edilmemelidir. Markalar bu iletişim özelliğini reklamlarında bir rekabet yarışı olarak kullanmaktadır. İletişim özelliğini daha basit olarak anlatmak gerekirse çiçeklerin simgeledikleri anlamlar gibi ifade edilebilir. Kırmızı gül'ün aşkı sevgiyi ifade etmesi örnek olarak verilebilir. Mobilyalarında kullanıcılarına veya kullanıcıları o mobilyayı tercih ederek çevrelerine göstermek istedikleri ifade bu sözsüz iletişim özelliği ile sağlanmaktadır.

Simgesel işlev; bir objenin algılanması aşamasında geçmiş deneyimlerden veya anılardan etkiler taşıyorsa o ürün kullanıcı açısından simgesel olarak da işlevini yerine getirmektedir. Bununla birlikte kullanıcı tercihleri aynı zamanda kullanıcıları hakkında ip uçlarıda sunmaktadır. Aynı ürünü tercih eden kişiler belli bir sosyo-kültürel kesimi oluşturmaktadır. Bu tercih edilen üründe o sosyal yaşamı simgelemektedir. $\mathrm{Bu}$ yönden de belli bir sosyo-kültürel seviyede olmak isteyen kullanıcı tercihini o mobilyalar yönünde yapmaktadır. Bu sembolik etki belli bir tasarım üslubunu kullanıcısına aktarıyor olabileceği gibi bir döneme veya anlayışa simge olarak Şekil 5 ve 6'da görüldüğü üzere kendi başına adeta bir heykel haline gelmiş mobilyalarda görüldüğü gibi tasarımcısının da bir sembolü, imzası olma niteliği de gösterebilmektedir.

Estetik ve simgesel işlevler birbiri içine geçmiş etkilerdir. Beğeni ve tercihleri etkileyen estetik işlevin kökeninde psikolojik olgular, geçmiş deneyim ve anılar ve kültürel yapı vardır. Bunlara hitap eden bir mobilya aynı zamanda simgesel işlevini de yerine getirmekte ve tercih edilmektedir. Bununla birlikte tasarlanan mobilya kullanım aşamasında kullanıcıya üretildiği veya tasarlandığı kurum hakkında bir takım ipuçları sunuyorsa yani kurumun veya markanın bir sembolü haline gelmiş ve bunu kullanıcıya aktarıyorsa o ürün artık bir kurumsal veya markasal simge olmuş demektir ve estetik değerlerle birlikte simgesel işlevini de yerine getiriyor demektir.

$\mathrm{Bu}$ üç işlev birbirleri ile etkileşimli olarak mobilya biçimlendirilmesinde ve tercihlere yol gösterici olması açısından ana etkenlerdir. Bir mobilyadan öncelikli beklenti bu çözümlemeler ışığında oluşmaktadır. Bu üç başlık birbirleri ile etkileşimli olarak tasarımcının tercihi yönünde baskınlıkları değişiklik gösterebilmekte ve biçim oluşturmada öncülük etmektedir.
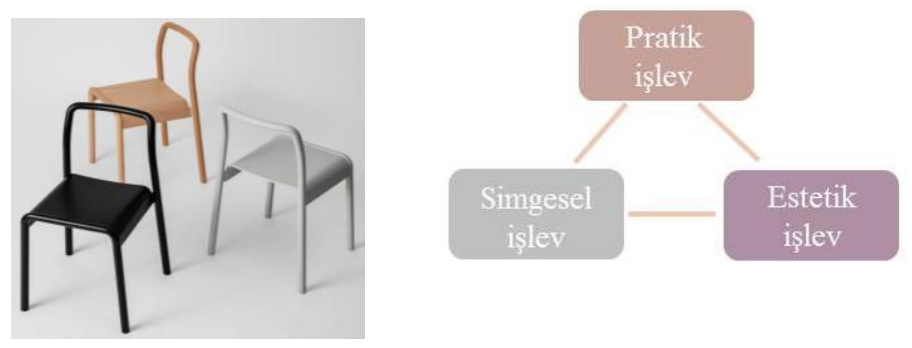

Şekil 1. Pratik Işslevi baskın oturma elemanı (Url-1) Şekil 2. Pratik-simgesel -estetik işlev ilişkiler şeması 

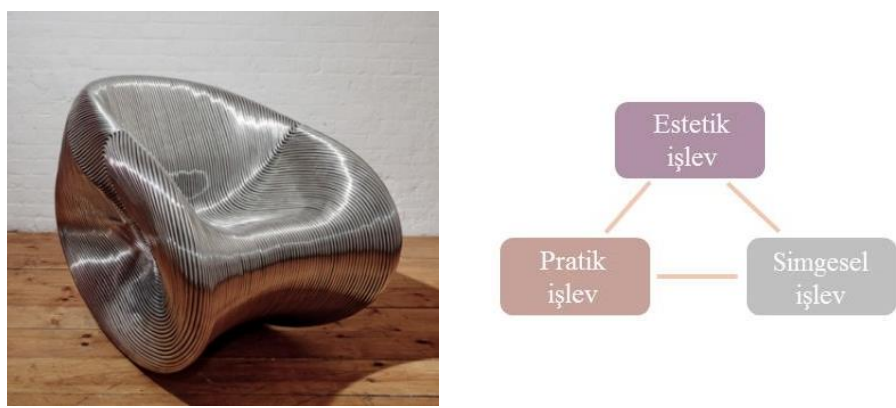

Şekil 3. Estetik işlevi baskın otuma elemanı Ron Arad tasarımı MT Rocker Solid, 2010 çelikten üretilmiş 6. edition (Url-2) Şekil 4. Estetik-pratik- simgesel işlev ilişkiler şeması
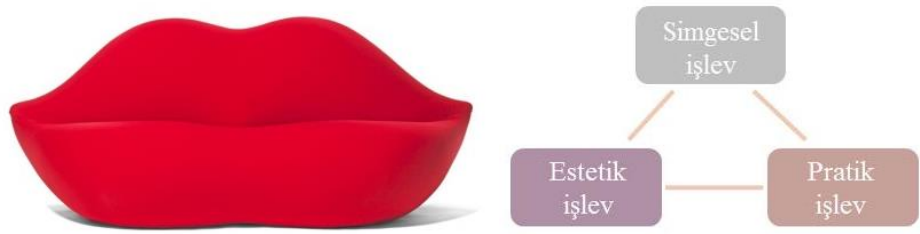

Şekil 5. Simgesel işlevi baskın Bocca studio65 tasarımı Poliüretan koltuk (Url-3)

Şekil 6. Simgesel-estetik-pratik-işlev ilişkiler şeması

\subsection{Tasarım ve Tercihi Etkileyen Faktörler}

Mobilya tasarım ve üretim süreci, ilk aşamasından itibaren çeşitli etkenlere bağlı olarak oluşmakta, biçimlenmekte ve hayata geçmektedir. Bir mobilyanın tasarlanması sürecinin ilk fikir oluşturulmasından, kullanımına geçmesine kadarki akışı etkileyen ve belirleyen pek çok etken ve etki vardır. Bu etken ve etkilerin birçoğu birbiri ile iç içe geçmiş etkileşimler kurgusudur. $\mathrm{Bu}$ kurguların netleştirilmesi aşamasında biçim yeniden ve yeniden oluşturulmaktadır. Kullanıcı beğeni ve tercihleri ile bu süreci yönlendirmektedir. Benzer bir şekilde hazır olarak sunulan mobilyalarda da bu iç içe geçmiş etki ve etkileşimler biçimi oluşturmakta sadece tasarımcı açısından daha geniş bir kitleye hitap edecek şekilde seçimleri yapılmakta ve biçimlenmekte, kullanıcı çoğu zaman bilinçsiz olarak benzerleri arasından tercihi yapmaktadır.

Tasarım ve tercihi etkileyen bu faktörler ortaya konularak bir mobilyayı satın alırken, sipariş ederken veya ihtiyaçları belirlerken kullanıcıya yön vermek ve ürünlere farklı bir gözle bakılmasının sağlanması hedeflenmektedir.

$\mathrm{Bu}$ başlıklar şu şeklide belirlenmiştir:

\subsubsection{Malzeme ve Yapım Yöntemi}

Mobilyanın biçimlendirilmesi aşamasında işlevden sonra gelen diğer önemli başlıktır. Malzeme tercihi mobilyanın biçimlenmesinde malzemenin sunabileceği imkânlar çerçevesinde etken rol üstlenmektedir. Biçimi oluşturabildiği gibi strüktür olarak mobilyanın ayakta durmasını sağlamaktadır. Ayrıca onu sararak ve bir manada giydirmektedir. İnsanın strüktürünü saran derisi gibi malzemede mobilyayı sararak biçimi tamamlamaktadır.

Malzemeler; mobilya tasarım ve biçimlendirmesinde iki yöntemde kullanıldıkları görülmektedir. Birinci aşamada taşıyıcı sistemi olarak görev almaktadır. Dışardan bakıldığında algılanabileceği gibi tamamen içe saklandığı çözümlerde görülmektedir. Kimi zamansa Şekil 7 ve 8 'de görüleceği gibi strüktür görevi üstenen malzemenin başka bir eklentiye veya kaplamaya ihtyaç duyulmadan kullanıldığı görülmektedir. Malzemeyi ikinci olarak mobilyayı kaplayarak ona son biçimini vermesi aşamasıdır. Strüktüründen tamamen farklı çeşitli dolgular ve tekstil malzemelerle giydirilmiş pek çok mobilya kullanılmaktadır. Bazı tasarımlar ve onların gerçekleşmesine sağlayan malzemelerin sunduğu imkânlar; herhangi ek bir strüktür malzemesi veya çözümüne ihtiyaç kalmadan hem kaplama hem ayakta durma ihtiyacını karşılayabilmektedir.

Yapım yöntemi malzemeye bağımlı bir başlıktır. Kullanım yeri yani çevre faktörü ile ilişkilidir. Örneğin; ahşap bir oturma elemanı için nerede kullanılacağına bağlı olarak tercih edilecek ahşaptan, mobilya üretim aşamasına geçmeden o ahşaba uygulanacak işlemlere ve yapım yönteminde kullanılacak geçme sistemlere veya ek parçalara kadar etken bir rol üstlenmektedir. Mobilyanın kullanılacağı çevreye bağlı olarak malzeme düşünülmekte yapım yöntemi düşünülmekte, seçilmekte ve biçimlendirme yapılmaktadır.

Günümüz teknolojik gelişmeleri, malzeme tercihleri ve geliştirilmiş üretim teknolojileri sayesinde artık biçim aynı kalacak şekilde, aynı mobilya çok farklı malzemelerle farklı konumlarda kullanılabilmektedir. Buradaki en etken faktör maliyettir. Kullanıcının ekonomik düzeyi, sosyo-kültürel düzeyi, bağlı olduğu toplumsal sınıf veya statü, beğeni ve tercihlerine bağlı olarak aynı biçim ve görüntü çok farklı maliyetlerle üretilebilmektedir. Bu noktada dikkat edilmesi gereken malzeme seçimi aşamasında mobilya, tasarımcısının ön gördüğü malzemelerden farklı alternatif bir çözüm ile üretilecek ise beklenen konfor şartlarının kaybedilmemesi ve ürünün kullanım ömrünü etkilememesidir.

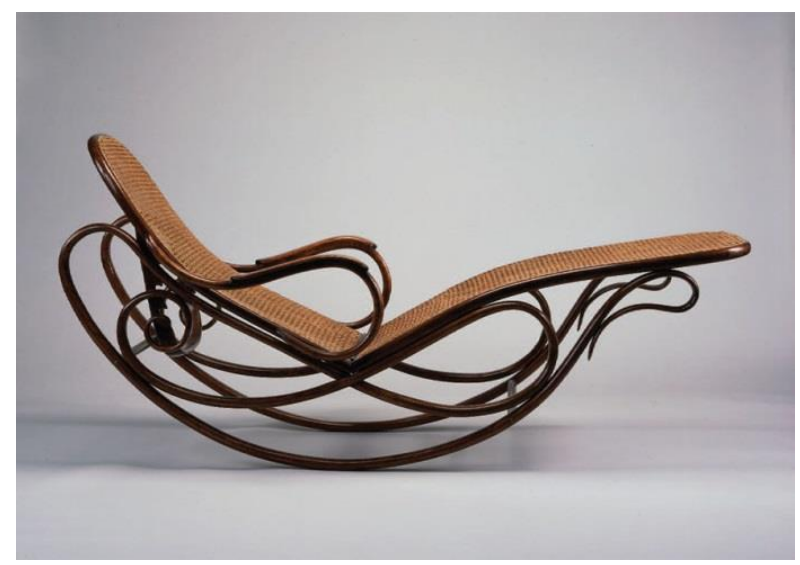

Şekil 7. Michael Thonet tasarımı Rocking Chair1880.(Url-4)

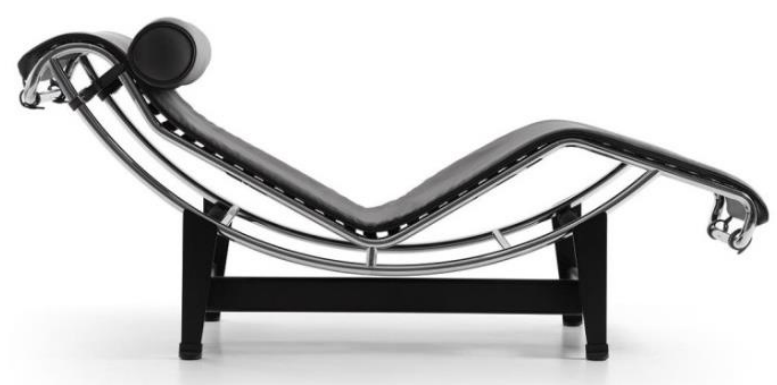

Şekil 8. LC4 adll Charlotte Perriand, Le Corbusier, Pierre Jeanneret tasarımı 1928.(Url-5) 


\subsection{2 Ölçülendirme, Uyum ve Ağırlık}

Tüm mobilyaların insanın beden ölçülerine yani dünya çapında kabul edilen ortalama antropometrik ölçütlere uygun biçimde ölçülendirilerek üretilmesi esastır. Bu sayede kullanıcı o mobilyayı kullanarak yaptığı eylemi en verimli şekilde yerine getirecektir. Şekil 9'da görüleceği gibi bedeni ile uyumlu olarak tasarlanan mobilya ilk kullanmaya başladığı andaki konforu saatler sonrasında da kullanıcısına sunabilmektedir. Benzer bir şekilde hareketli bir mobilya olarak tasarlanmış bir ürün kullanıcısına zorluk çıkartmadan ağırlık ve biçimi itibari ile kolaylıkla hareket ettirilebilmeli ve yeri değiştirilebilmelidir.

Ancak Şekil 10 ve 11'de görüleceği gibi özel üretimler söz konusu olduğunda kullanıcısı düşünülerek ve hatta kullanıcısına uygun olarak ölçülendirilmesi ve biçinlendirilmesi gerekmektedir. Antropometrik olarak her ne kadar standart ölçü aralıkları kabul edilmişse de Şekil 12'de görüleceği gibi özel ölçülere sahip çocuklar, yaşlılar ve engelliler için gereken farklı çözümler üretilmelidir. Bu noktada hareketli olarak düşünülen mobilyaların ağırlıklarının da göz önünde bulundurulması gerekmektedir. Malzeme seçimleri de bu özel ölçülere ve kullanımlara uygun olacak şekilde yapılmalıdır.

Uzun süreli kullanımlarda karşılaşılabilecek bedensel rahatsızlıklara neden olmayan kullanıcısına konforu en uzun süre sağlayabilen ve özellikle çalışma ortamında işini engellemeden yürütmesini sağlayabilecek ölçülerde ve biçimlerde mobilyalar üretilmelidir. Seri üretim mobilyaların özellikle çalışma sandalyelerinde çok daha geniş bir kullanıcı kesimine hitap edebilmesi için kendi içinde değişebilir ölçülere sahip kullanıcısına hareket edebilir olma, değişebilir, ölçüler ve yükseklikler ile maksimum konforu sunan tasarım çözümleri üretilmektedir. Sandalye yükselip alçalabilmekte sırtlık açısı ve baş desteği açıları değişebilmektedir. Bunun gibi araç koltuklarında da artık farklı kullanıcıların konfor ölçülerini hafizasinda saklayabilen koltuklar üretilmekte ve kullanılmaktadır.

Bunların yanı sıra özel şartlarda örneğin; kullanım süresinin kısa tututlması istenilen şartlarda malzeme seçimi ön plandadır. Tasarım ve ölçüler açısından gerekli konforu sunan bir oturma elemanı tercih edilen malzemesi nedeniyle uzun oturmaları desteklemeyecek rahatsızlık verecek şekilde seçilebilmektedir. Fast food restoranları veya alışveriş merkezlerindeki foodcourtlarda kullanılan oturma elemanları bu şartlarla tasarlanmaktadır.

Ölçülendirme, kullanıcı ile uyum ve ağırlık bu noktalarda malzeme seçimleri ile birlikte ortak alınması gerekli kararlar arasindadir.

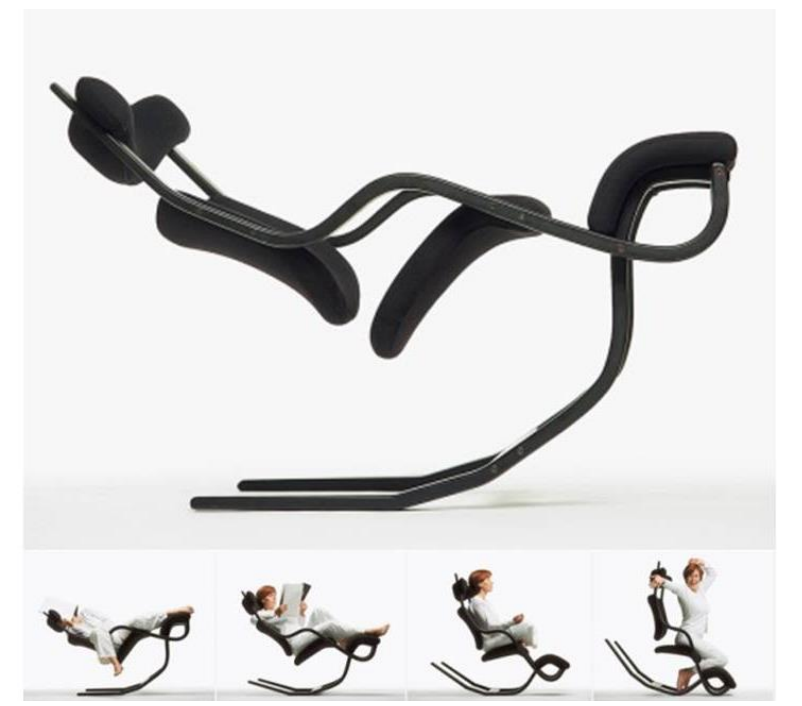

Şekil 9. Zero Gravity Balans sandalye Peter Opsvik tasarımı 1983 (Url-6)

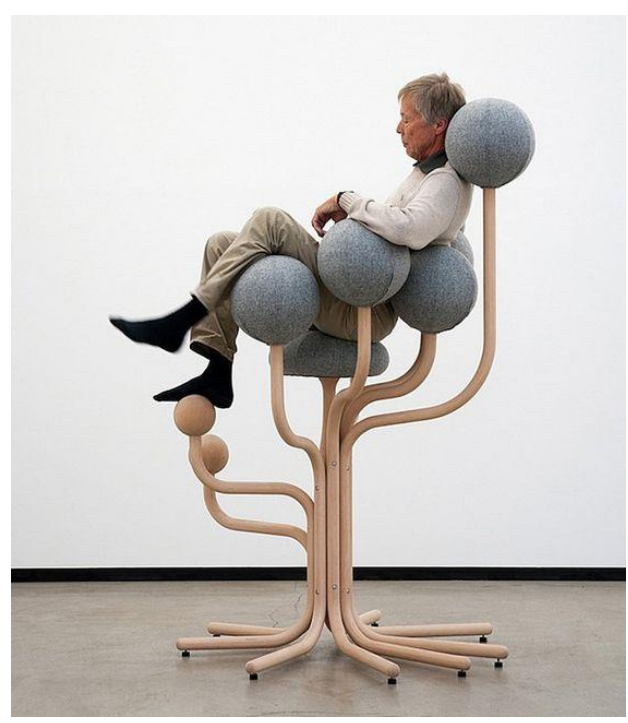

Şekil 10. Peter Opsvik in Garden concept koltuğu 1986 (Url-7)

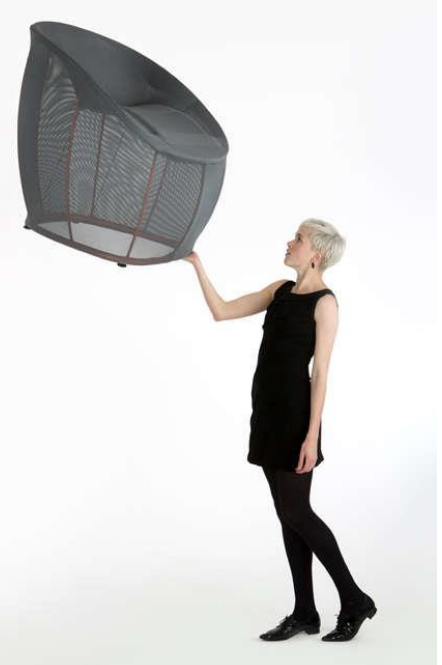

Şekil 11.Tek elle taşınabilir hafiflikte oturma elemanı, ince çelik bir strüktür ve üstünü kaplayan yastık entegre edilmiş kılıf(Url- 


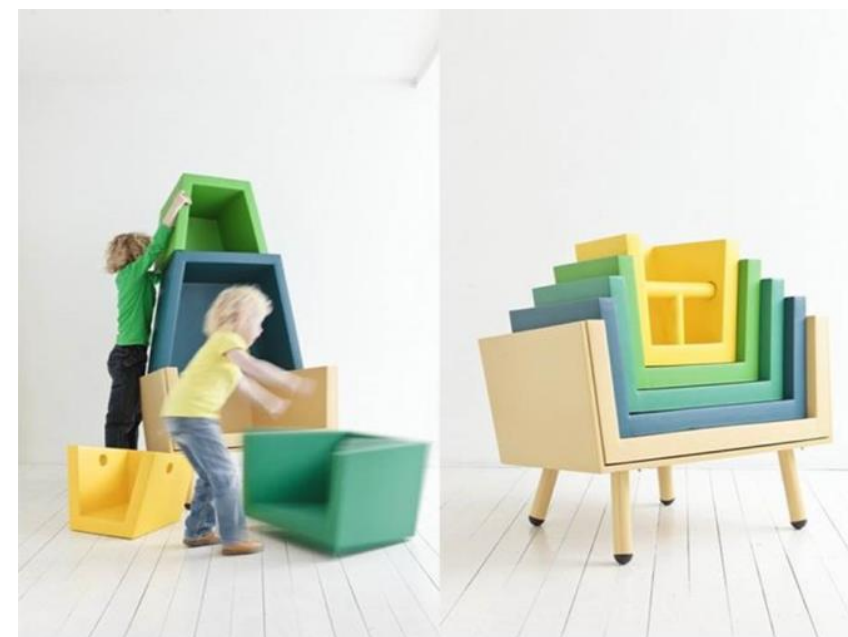

Şekil 12.Çocuklar için hem oyun hem de mobilyanın hafifliği sayesinde kurgusu değiștirilebilmesi (Url-9)

\subsubsection{Hiyerarşi ve Statü}

Geçmişinden bu güne mobilya bir statü göstergesi olma özelliğini korumaktadır. Markalarla bu statü etkisi artmakta, kullanılan malzemeler ve moda etkisi ile daha da kuvvetlenmektedir. Günümüzde mobilyaların kendi aralarında da bir hiyerarşik düzen oluşturdukları görülmektedir. Aynı mekân içinde kullanılan mobilyalar arasında bir takım ekler ile aynı işleve cevap veren mobilyalar birbirleri arasında bir bütünlük ve hiyerarşik düzen oluşturabilmektedir. Birçok oturma elemanın bulunduğu bir mekânda rengi malzemesi ve albenisi ile öne çıkan diğerlerinden baskın mobilyalar göze çarpmaktadır. İç mekânların düzenlenmesinde bu etkideki mobilyalar özel olarak yerleştirilmekte ve mekânın kimliğini işlevini biçimlenişini ve iç sirkülasyonunu düzenlemekte kullanılmaktadır.

Bir ofis tasarmında kullanılacak mobilyalar arasındaki çalışma masası sandalyeleri veya masalar hiyerarşik düzenin en net okunabildiği mobilya örnekleridir. Bir yöneticinin çalışma sandalyesinin sırtlığı yüksek, kolçaklı ve başlıklı bir çalışma sandalyesi iken, alt departmanlardaki çalı̧̧ma sandalyelerin sırtlığı ise daha alçak ve kimi zaman kolçaksızdır. Aynı işleve hizmet veren iki oturma elemanı arasındaki hiyerarşik fark mobilyaya bu şekilde yansımaktadır. Benzer bir durum Şekil 13 'de görüleceği gibi dikdörtgen ve daire yemek masası çevresine yerleştirilen sandalyelerde de görülmektedir. Dikdörtgen, biçimi itibari ile dairenin eşitlik etkisinden farklı olarak hiyerarşi düzeni oluşturmaktadır. Masa başına getirilen sandalyeler kimi zaman kolçaklı tercih edilmektedir. Bu sayede masa başında oturanların ev sahibi oldukları veya ailenin en büyükleri oldukları yani statü olarak diğer kişilerden daha farklı oldukları sessiz bir dille yansitılmaktadır.

Genel olarak mobilya tercihleri ana hizmet işlevine cevap verebilecek yaşam döngüsünün gerekliliğini karşılayacak tercihler üzerinden yapılmaktadır. Ancak kullanıcı, bulunduğu toplumsal yapı içindeki varlığını simgelemesi açısından da ihtiyaçlarını belirlemekte ve mobilyalarını tercih etmektedir. Toplum içindeki statü bir sözleşme veya yasalar tarafindan belirtilen şartlar ile elde edilmektedir. Bireyler bu kazandıkları statülerini üniformaları, kimlikleri, yüzük ya da arma gibi sembollarle çevrelerine yansıtmaktadırlar. Tercihlerini de statüsünü destekleyen seçimler yaparak göstermektedir. Mobilyanın iletişim özelliğinin baskın çıktığı bu aşamada kullanıcı eğilimi her zaman bir üst sınıfta veya statüde olmaktır ve bu talebini destekliyecek ürünler için mevcut imkânlarını zorlamakta ve o ürüne sahip olmaktadır. Bu aşamada İhtiyaç ana işlevin dışına çıkmakta hatta ön plana geçmete ve tercihi belirlemektedir. Artık kullanıcı için gerçekten o mobilyaya ihtiyacı olup olmadı $\breve{g} 1$ önemini kaybetmektedir. Özellikle ekonomik sınırlarını zorlamadığı takdirde kullanıcı ihtiyacı dışındaki ürünü satın almaktadır.

Benzer şekilde gerçekten ihtiyaç olamadığı halde satın alınan ve kullanılan takım mobilyalarının bir parçası olarak iç mekânlarda yerini alan, toplum içinde ayrıcalıklı olarak görünmek ve özgün eserlere sahip olma ihtiyacının ortaya çıkardığ tasarımcıları biçimlendirmeye yönlendiren mobilyalar vardır. Bunlar Şekil 14'de görüleceği gibi gümüşlük, vitrinler ve büfeler gibi bu özgün değerli antika eserlerin saklandığı ve kullanıcısına istediği toplumsal grup içinde olduğunu hissettirmekte ve istediği statüyü sunmaktadır.

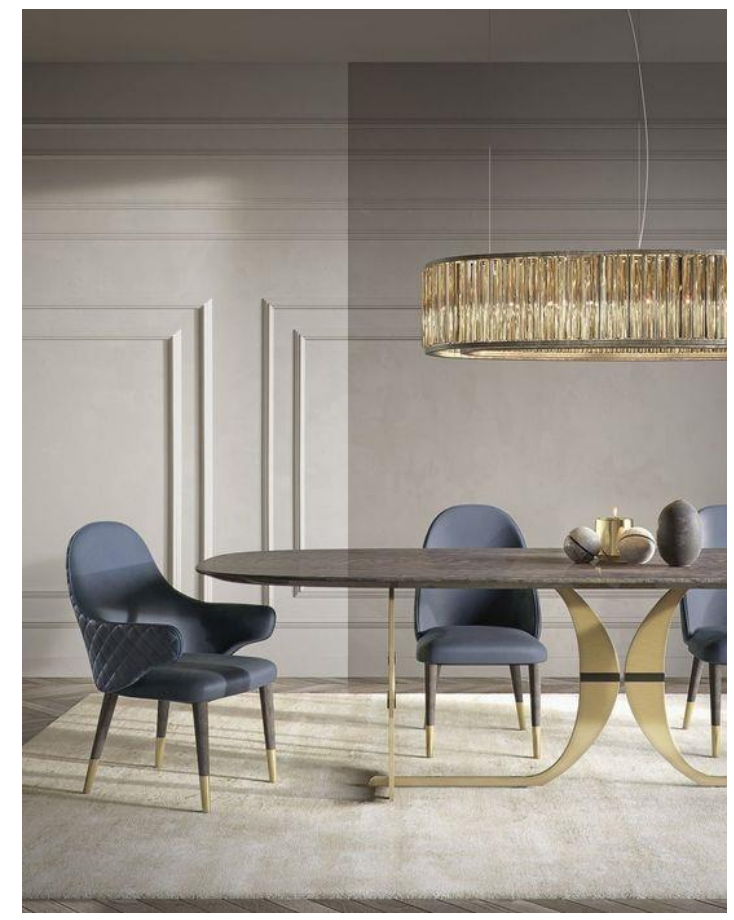

Şekil 13. Hiyerarşi örneği masa başı kolçakll, masa yanları kolçaksız sandalyeli düzenlemesi (Url-10)

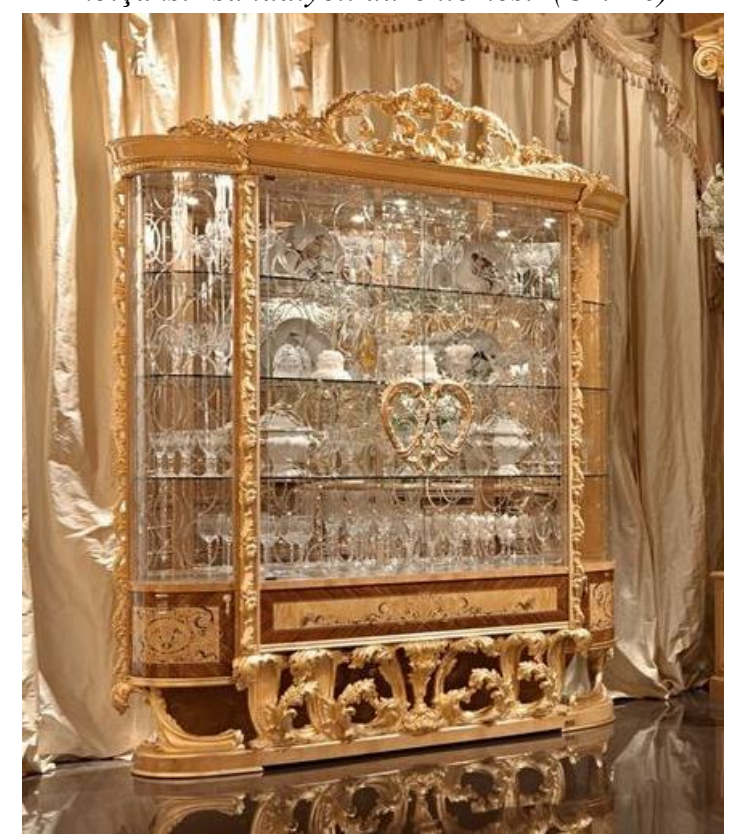

Şekil 14. Gümüşlük-vitrin örneği (Url-11) 


\subsubsection{Maliyet}

Malzeme seçimine ve yapım yöntemine bağlı olarak günümüz üretim teknolojileri sayesinde Şekil 15 ve 16'da görüleceği gibi aynı görünüm farklı veya alternatif malzemeler ile de sağlanabilmektedir. Bu sayede çok daha düşük maliyetlerle mobilya üretilebilmektedir. Maliyet bu aşamada tercihlerle devreye girmektedir. Statü ve iletişim etkisi ile kullanıcı bütçesi üzerinde tercih yapabilmektedir. Ancak uygun malzeme tercihleri ve yapım yöntemleri ile maliyet belirli oranda düşürülebilmektedir.

Belirlenen bütçeye göre malzeme ve yapım yöntemleri seçilirken kullanılacak ürünün kullanım ömrüde hesaba katılarak tasarım oluşturulmaktadır. Ödün verilmemesi gerekli noktalardan birisi maliyetin düşürülmesi mamcıyla yapılacak farklı malzeme tercihleri ürünlerin kullanım süresinin beklenenden önce tamamlaması kırılması bozulması ve işlevsiz hale gelmesidir.

Seçilen malzeme ile maliyetin hesaplanmasındaki bir diğer çözümlenmesi gereken nokta ise yapım yöntemi tercihleri ile devreye giren kalıp maliyetidir. Elde edilmek istenen biçime ulaşmak için seçilen malzemeye bağlı olarak yapılması gereken kalıp ancak belirli bir sayıdaki üretimlerle kalıp maliyeti çıkartılabilmektedir. Kalıbın kullanımı ve ömrü de yine üretim sayısına bağlı olarak değişiklik göstermekte ve zamanla yıpranmaktadır. Bu nedenle tek bir ürün için yapılacak maliyet hesaplarında özel bir kalıp üretilmesi de söz konusu ise bu husus gözönünde bulundurulmalı, farklı bir malzeme ile veya üretim yöntemi ile çözüm oluşturulmalıdır.

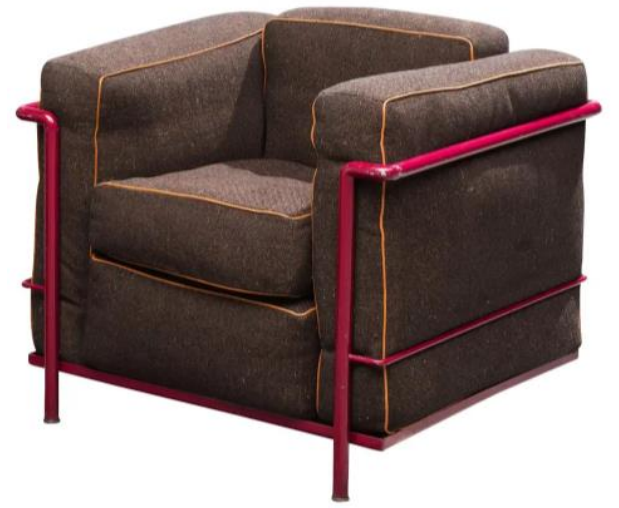

Şekil 15. LC2 koltuk çelik ve kumaş Le Corbusier tasarımı 1928. (Url-12)

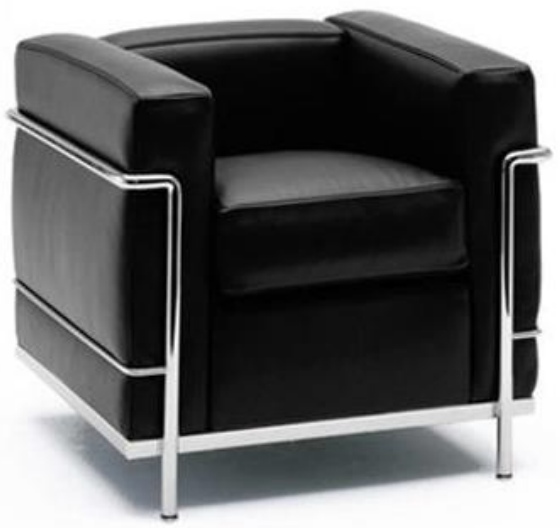

\subsubsection{Toplumsal Gelenek ve Alışkanlıklar}

Kişi dünyaya geldiği aile düzeni içinde yaşadığı toplumun genel değer yargısını, alışkanlıklarını ve yazılı olamayan ama gelenek-görenek olarak adlandırılan kurallarını öğrenerek ve uyarak o toplumun bir parçası olarak yaşamaktadır. Bu kurallar, belli zaman dilimlerindeki alışkanlıklar, teknolojik gelişmeler ve küreselleşme gibi etkiler ile gelişime uğrayabilmekte ve değişebilmektedir.

Toplumun değer yargılarını ise bu kurallar ve yasalar çevçevesinde yaşayan insanların tercihlerini yani ekonomiye bağlı arz talep düzenini belirlemektedir. Değer yargılarının gelişimi ve değişimi; bu arz talep dengesi içine katılan değer yargılarını zorlayan ve hatta onlara karşı gelen eserler ve ürünlerin öncelikle belli bir kesimce ve sonrasında genelin kabul etmesi ile oluşmaktadır. Tasarımcı sunduğu ürünün kabul görmesi ile yeni tasarımlar yapmaya yönelerek özgüvenini kazanırken kullanıcı bu farklı tasarımların sahibi olarak statüsünü pekiştirmekte ve duyusal tatmine erişmektedir. Moda faktörünün gelişmesi ile bu değerler düzeni farklılıkları daha kolay kabul edebilir hale gelmektedir. Moda ve ürünlerin, tasarımların taşıdığ 1 iletişim özelliği sayesinde diğer toplumların kültürlerini, yaşam biçimlerini etkilemekte geliştirmek ve değişime uğratmaktadır.

Toplumsal geleneklerine bağlı, ahlaki inançları ve alışkanlıkları baskın, içine kapalı toplumlar belli başlı konulardaki alışkanlıklarından vazgeçmeyerek ilk günki kadar katı olmasada halen devam ettirmektedirler. Yemek yeme alışkanlıkları örneğin Şekil 17'de görüleceği gibi Japon kültüründe farklı bir oturma yüksekliğinde ve seramoni şeklinde gerçekleştirilmektedir. Benzer bir fark inançların etkisiyle akan su veya durağan su ile yıkanma alışkanlıklarında da görülmektedir. Tasarımlara ve çözümlemelere ayaklı küvetler veya hızla yıkanılabilecek duş teknelerinin tasarlanması ile yansımaktadır. Taret musluğu gibi özel çözüm ve tasarımlar günlük hayata yerleşmiş ürünler olarak süre gelmektedir.

Türk evi yaşam düzenine bakıldığında Şekil 18'de görüleceği gibi yere yakın sedirlerde bağdaş kurarak veya ayaklar toplanıp alta alınarak oturmaya imkân sunan ölçülerde, oturma alanı geniş ve alçak olarak düzenlenmekteydi. Günümüz mobilyalarında bu ölçüler kullanıcı talebine göre değişkenlik gösterebilmektedir. Bu ölçülerin bir diğer sebebi ateş yanan tek mekânda gündüz otuma ve yaşama işlevini karşılayan bu mekân akşam sedirler üzerine serilen örtülerle yataklara dönüşerek yatma mekânı olarak kullanılmaktaydı. Ayrıca bu dönüşüm yer sofralarında; yemek zamanı açılır kapanır ahşap ayaklar üzerine sini adındaki büyük tepsinin getirilmesi ve hane halkının bu sini çevresinde yere oturarak yemek yemeleri sonrasında o mekânın tekrar yaşama mekânına dönüşümünde de görülmektedir. Günümüzde bu alışkanlıklar yerini yüksek masalara ve yemek sandalyelerine dönüşmüştür. Ancak halen kullanıcıların talepleri üzerine sekili ve sedirli oda düzenleri özellikle cumbalı yapılarda oluşturulmaktadır.
Şekil 16. LC2 koltuk krom çelik ve deri Le Corbusier tasarımı 1928. (Url-13) 


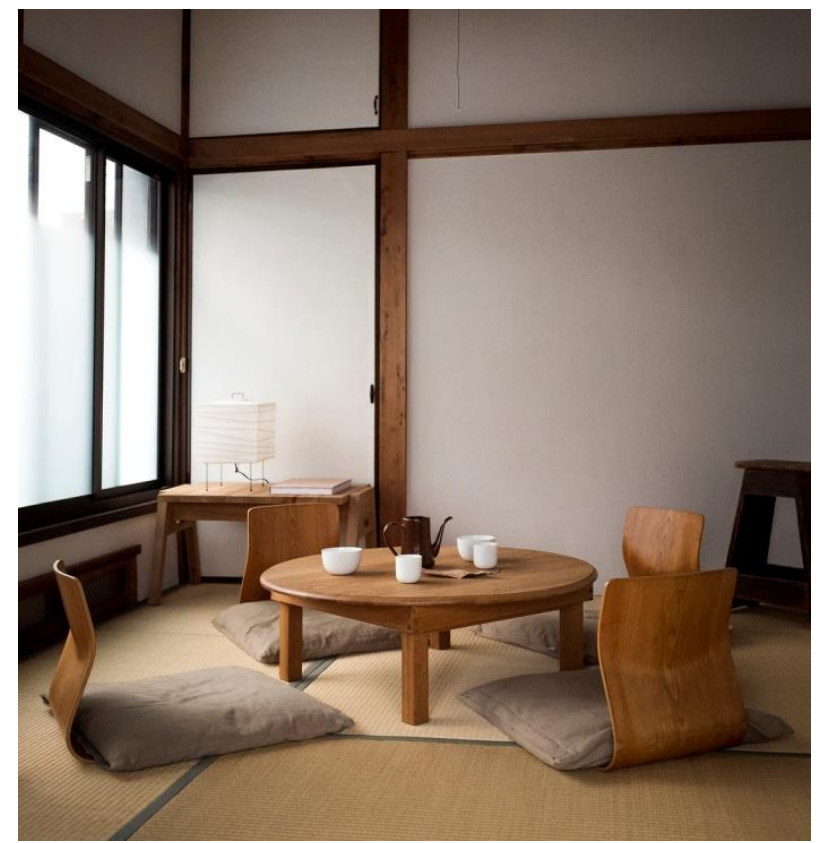

Şekil 17. Uzak doğu kültürü yerde oturarak yemek düzeni (Url-

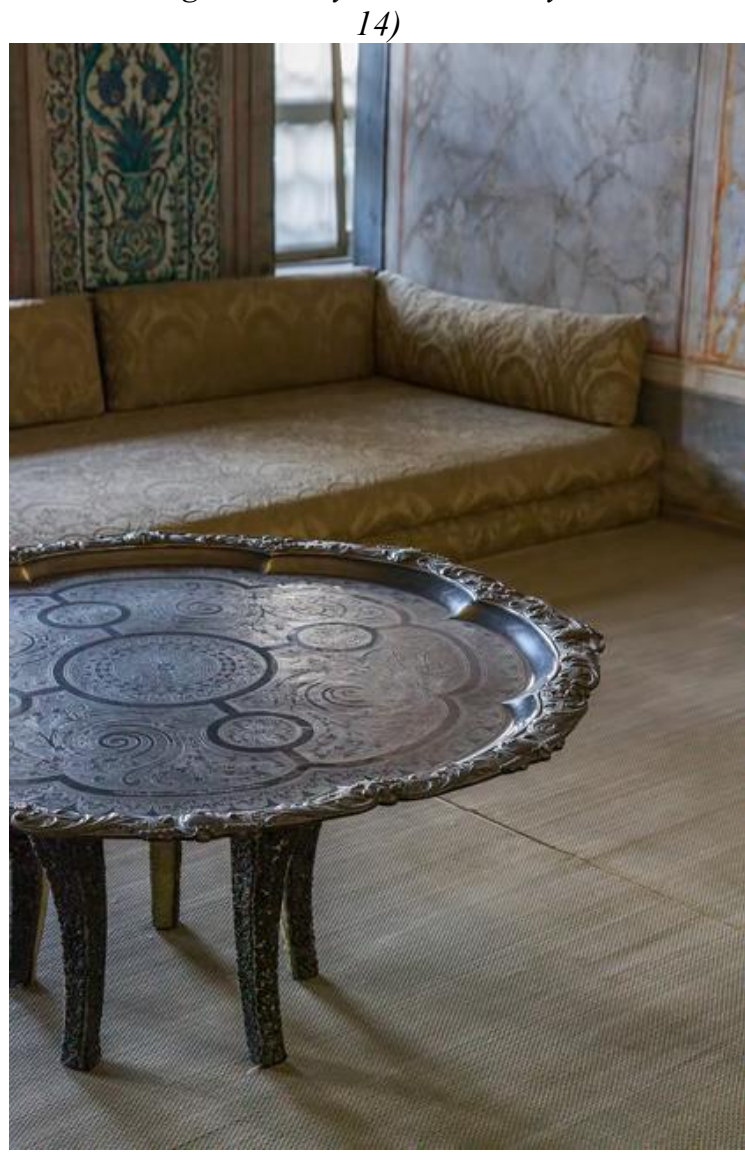

Şekil 18. Sedir oturma ve sini örneği (Url-15)

\subsubsection{Moda ve sanat akımları}

Modanın gelişim sürecine bakıldığında; insanın bedenini sarmak ve koruma için kullanmaya başladığ giysileri, kültürel ve sosyal ilişkiler, gelişimler ile değişmiş ve çeşitlenmiştir. $\mathrm{Bu}$ eylem zaman içinde yeni iş kollarına dönüşmüş ve kültürel alanda moda ve akımlarının oluşturulmasını sağlamıştır. Bu yeni iş alanı, geniş kitleleri kısa dönemlerde etkileyen modanın ve akımlarının doğmasına neden olmuştur.

Kişinin simgesel algısı ve dünyasının, tamamen kültürel etkilerden oluşması gibi moda kavramı mobilya tasarım ve biçimlenmesi sürecinde de kültürel bir hareket anlamı taşımaktadır. Tasarımcı modanın sunduğu etkiler ve semboller ile kullanıcısına aktarmak istediği mesajı mobilyasına yükleyebilmektedir.

Tasarımcı mobilyasındaki moda etkisini; renk, malzeme, doku gibi biçime son halini veren elemanlarla oluşturulabildiği gibi bir mobilya kendi başına bir moda akımının öncüsü olabilmektedir. Benzer şekilde tasarımcı da kendi başına ortaya koyduğu ürünü ile bir moda faktörü oluşturabilmektedir.

Moda tercihler üzerinde etkindir. Kullanıcı bulunduğu toplumsal yapıyı sergilemek veya statüsünü pekiştirmek için moda olan ürünü tercih etmektedir. Bütçesinin sınırlarını zorlaması veya ana işlevi nedeniyle gerçek bir ihtiyacı karşılayıp karşılamadığının önemi olmaksızın kullancı o ürüne sahip olmayı istemekte ve satın almaktadır. Modanın talep üzerindeki bu etkisi tasarımcıyı da yeni, farklı ve daha gelişmiş ürünler ortaya çıkartmaya yöneltmektedir. $\mathrm{Bu}$ arz talep sistemi kendi içinde hem yeni moda akımlarının oluşmasını hemde ürün çeşitliliğin gelişmesini desteklemektedir. Tasarımcıyı tetikleyen ve yeni tasarımlar ortaya koyması gerekliliğini doğuran bir diğer neden ise modanın öncü çizgilerini taşıyan ürünlerin zamanla benzerlerinin daha düşük maliyetlerle geniş kitlelerin alımına sunulması ile orijinal tasarımların değerini kaybetmesi sonucu ortaya çıkmaktadır. Bu durumda tasarımcı daha yeni ve farklı biçim arayışlarına gitmek zorunda kalmaktadır.

Diğer sanatçılardan kendini ayıran, toplumun önüne geçerek diğer insanlar ve sanatçılardan daha derin ve duyarlı bir bakışla alg1 ve kavramları cisimlendirebilen sanatçılar kendi alanlarında üslup getiren sanatçılardır. Onlar modanın ötesinde toplumu daha geniş çapta etkilemekte ve yeni bir tasarım dili oluşturmaktadırlar. Sanat akımlarının kurucusu ve öncüsü olmaktalardır. Bir üslubu benimseyerek Şekil 19 ve 20'de görüleceği gibi kendi özgün eserlerini ortaya koyan tasarımcılar da vardır. Üslup getiren ve özgün eserler ortaya çıkartan sanatçıların ellerden çıkan tasarım ve biçimler zamana meydan okuyan her dönem değerlerini ve özelliklerini kaybetmeden taşıyan ürünlere dönüşmektedir.

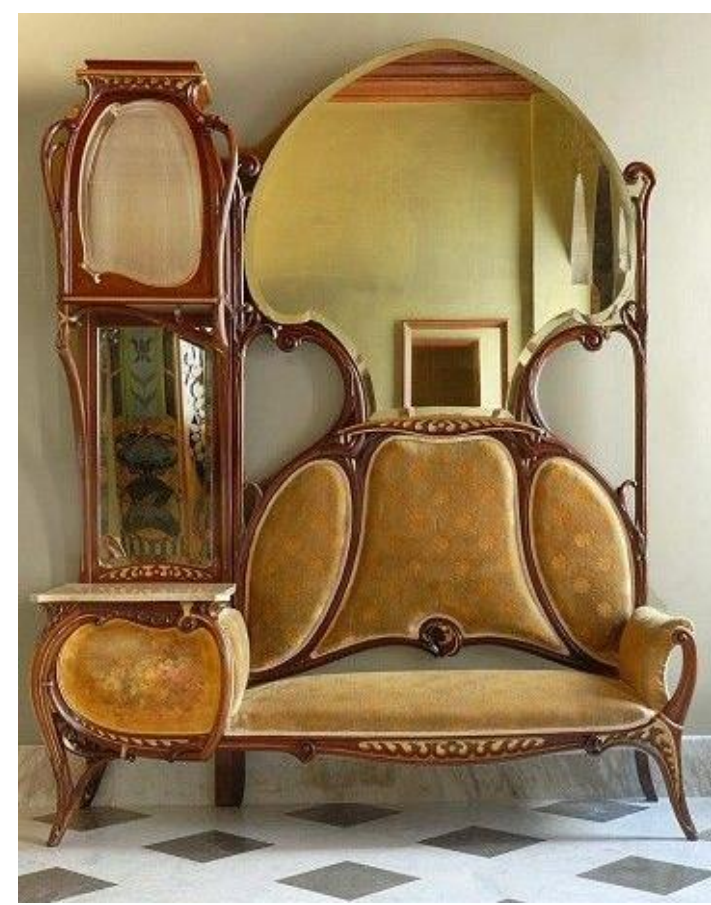

Şekil 19. Gaudi'nin artnouvea etkisindeki özel tasarım mobilyası (Url-16) 


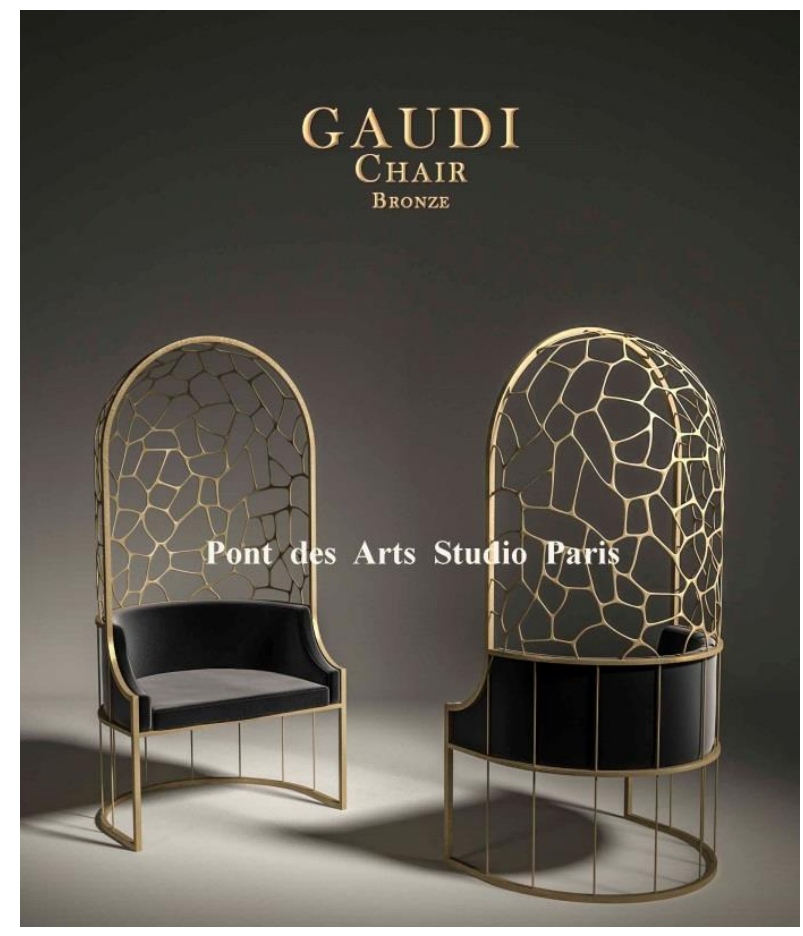

Şekil 20. Pont des Arts markasının mobilyası 2019 (Url-17)

\subsubsection{Algı Yetileri ve Psikoloji}

Tasarımcının vermek istediği mesaja bağlı olarak yapacağı malzeme seçimi ve biçim ile kullanıcının üstünde bırakmak istediği etkiyi değiştirebilmektedir. Kullanıcının tercihlerinde; toplumsal değer yargıları, kişisel alışkanlıkları gibi farkında olmadan etkilendiği faktörlerin yanı sıra ürünün kaplamasındaki farklı bir yön, renk, doku gibi beğenisine hitap eden özellikleri ile kullanıcı farklı tercihler yapabilmektedir. Bazen aynı biçimin farklı yüzey kaplaması kullanılmış alternatifi, yüzeyin yatay veya düşey kaplanmış olması algılamadaki etkiyi değiştirmekte ve tercih noktasında etkin olabilmektedir. Çeşitli algı oyunlarını, tasarımcı vermek istediği mesajı saklamak için bir yöntem olarak kullanabilmektedir.

\subsubsection{Tasarımcı Kimliği}

Mobilya tasarımının özü; insanlar için tasarlanması, üretilmesi ve satılmasıdır. Ancak ürünler arasındaki farkları ve bunca çeşitlilğin sebebi, tasarımcı ve kullanıcıların farklı kimliklere ve karakterlere sahip olmalarıdır. Aynı pratik işleve cevap verecek aynı mekân için kullanılabilecek farklı kimliklerde biçimlerde ve tarzlarda mobilyalar üretilmektedir. $\mathrm{Bu}$ farklılık sadece tasarımcı ve kullanıcı kimlikleri veya karakterlerindeki farklar ile değil aynı zamanda toplumun kültürel yapısı, alışkanlıkları, mobilyaların üstlendikleri iletişim görevi ve tasarımcının her yeni tasarımında özgün eser ortaya çıkartma çabası ile kullanıcının bu çabayı destekleyen özgün esere sahip olma talebi ile oluşmaktadır.

Tasarımc1; yeteneği, ailesi ve yakın çevresi ile başlayan ve yasalar çerçevesinde belirlenmiş kurumlarca devam ettiği, son olarak da meslek eğitimi olarak adlandırılabilecek kimi zaman usta-çırak ilişkisi içeren tasarımcının talebe konumunda olduğu eğitim ile sözsüz iletişimi kullanarak, ortaya koyduğu anlatım dilini oluşturmaktadır. Resim, heykel ve mimarlık sanatlarında olduğu gibi sözsüz iletişim olarak adlandırılan bu dil ile tasarımcı iletmek istediği bilgi ve mesajı bir takım semboller kullanarak anlamlandırmakta ve kullanıcısına aktarmaktadır. $\mathrm{Bu}$ eğitim ile yeteneğini geliştirmekte biçimlendirmekte, bilgi ve beceri kazanarak tasarımlarına yansıtacağı bir kimlik oluşturmaktadır. Kullanıcının talepleri doğrultusunda ürünlere yansıyan bu kimlik gelişmektedir.

Tasarımcının yeteneği ve eğitimi ile yaptığı tasarımların sanat değeri taşımasını sağlayabilmektedir. Ortaya çıkan tasarım, geniş bir kullanıcı kesimine ulaşmış, beğeni kazanmış ve tercih görmüş ise başarı kazanmış bir ürün olarak değerlendirilir. Tasarımcı ürünlerinde; bir sanatçının grubun akımın veya dönemin izlerini kendi tasarım dili ile birleştirerek kullanmış ise ortaya konan tasarım bulunduğu döneme üslup kazandırmaktadır. Şekil 21'de görüleceği gibi kendi başına adeta bir heykel haline gelmiş bu mobilyalar tasarımcısının bir sembolü, imzası olma niteliği de gösterebilmektedir.

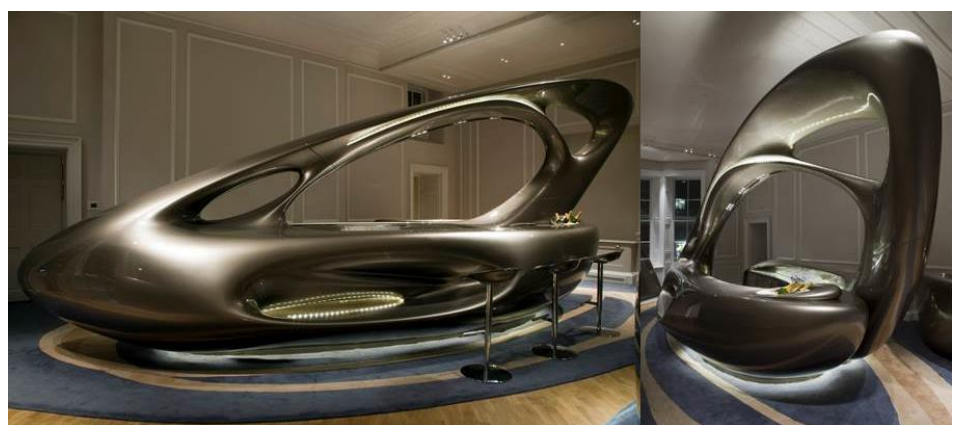

Şekil 21. Zaha Hadid tasarımı bar ünitesi (Url-18)

\subsection{9 Özel amaçlar, Dönüşüm, İstifleme, Boyut Küçültme ve Depolama}

Yaşam biçimlerindeki değişim ve dönüşüm, gelişen üretim teknolojileri, küreselleşme gibi unsurlar mobilyalar için de farklı biçimleniş etkenlerini oluşturmaktadır. Önceleri haneler; içinde iki kalabalık nesil barınabilecek, evlenen erkek çocuğun eşi ve ailesini dahi kabul edebilecek metrekarelere sahip iken kentleşme ve sanayileşme ile hane metrekareleri küçülmüş, aynı metrekare içinde büyük aileler yaşamak mecburiyetinde kalmışlardır. Küçülen mekân içinde birleşen eylemler ile birlikte bir mobilya birden fazla işlevi üstenmeye başlamıştır. Önceleri biçimleniş olarak etkilemese de sonrasında üstleneceği işlevler biçimlenişlerine de yansımıştır. Bir yatak uyuma, dinleme, çalışma ve hatta bir tepsi yardımı ile yemek masası işlevini üstlenmektedir. Ekonomik şartlardaki gelişimler, alım gücü artan toplumu etkilemiş, kendi bireysel iç mekanlaranı sahip olmaya başlamıştır. Ancak şehirlerin ve iş merkezlerinin çevresindeki bu yapılar gerekli artan ihtiyaca cevap verebilmek için birçok işlevi bir arada sunabilecek küçük metrekarelerde iç mekânlara dönüşmüştür. Tek bireyli yaşam alanlarına bu hızlı geçiş çok küçülen neredeyse 0+1olarak adlandırılabilecek o tek mekânda birden fazla işleve cevap verme durumunda kalmıştır. Tek odadan oluşan iç mekân içinde yer alacak mobilyalar da farklı işlevlere cevap verebilmesi için dönüşebilir şekilde biçimlenmektedir. Oturma, yatma, depolama, uzanma-dinlenme bir kısmında sehpa (hizmet servis elemanı) olabilme özelliklerini aynı anda barındırmak zorunda kalmaktadır. Tasarımcının birden fazla ana işlevi tek bir mobilyada toplaması, iki veya daha fazla olan ana işlevleri arasındaki dönüşümü kolaylıkla aşırı güç gerektirmeden yapılabilmesini sağlaması gerekmektedir. 
Mekânların küçülmesi mobilyaların birden fazla pratik işleve üstlenmesi için tek gerekçe değildir. Hane içinde yaşayan kişi sayısının azalması ile çekirdek aile kavramı artık sadece anne, baba ve kardeşleri içermektedir. Ancak mekânla birlikte oluşan bu aile birey sayısındaki küçülme kültürel etkilerin yok olmasına neden olmamaktadır. Yatılı misafirlikler çek-yat mobilyaların oluşmasını sağlamıştır. Yine kalabalık sofralar gerektiğinde büyüyerek daha kalabalık kişi sayısına hizmet verebilen masaların tasarlanmasını gerektirmiştir.

Boyutları sınırlı mekânlar, mobilyanın biçimlenmesinde ve tercih aşamasında farklı bir biçimde daha kendini göstermektedir. $\mathrm{Bu}$ çözümleme; işlevsiz kılma veya boyut küçültme olarak adlandırılmaktadır. Şekil 22'de görüleceği gibi ihtiyaç duyulduğunda kullanılan işlevini tamamladıktan sonra mekân içinde yer açmak amacı ile kapatılıp bir kenara kaldırılan yataklar ve sandalyeler ve geçici açılıp kapatılan yemek masaları gibi mobilyalarda tasarlanmakta ve tercih edilmektedir.

Bunların dışında özel amaçlarla kullanm için istiflenebilmek önemli çözümlerden biridir. Dönüşebilir mekanlar için workshop alanları konferans ve kongre salonları gibi mekanlarda kişi sayısına veya oturum sayısına bağlı olarak sandalyeler üstüste istiflenebilmekte gerektiğinde kullanıma sunulmaktadır. Başka bir çözüm ise biçimin basit tutulması ile farklı iç mekânlarda farklı amaçlarla kullanılabilen mobilyalarda tasarlanmaktadır. Salonda sehpa, yatakodasında komodin ve çalışma odasında kitaplık olarak kullanılabilen mobilyalar gibi.

Bunların dışında özel amaç mobilyaları arasında yazı masaları, kitap okuma koltukları, özel koleksiyonların teşhiri ve depolaması için yapılan camlı dolaplar veya kültürel etkilerle ortaya çıkan bir takım ihtiyaçlara cevap vermek için tasarlanan Şekil 23'de görüleceği gibi dedikodu koltuğu gibi, kullanıcısının talebi doğtrultusunda biçimlenen ve döneminin etkilerini taşıyan mobilyalar kullanılmaktadır.

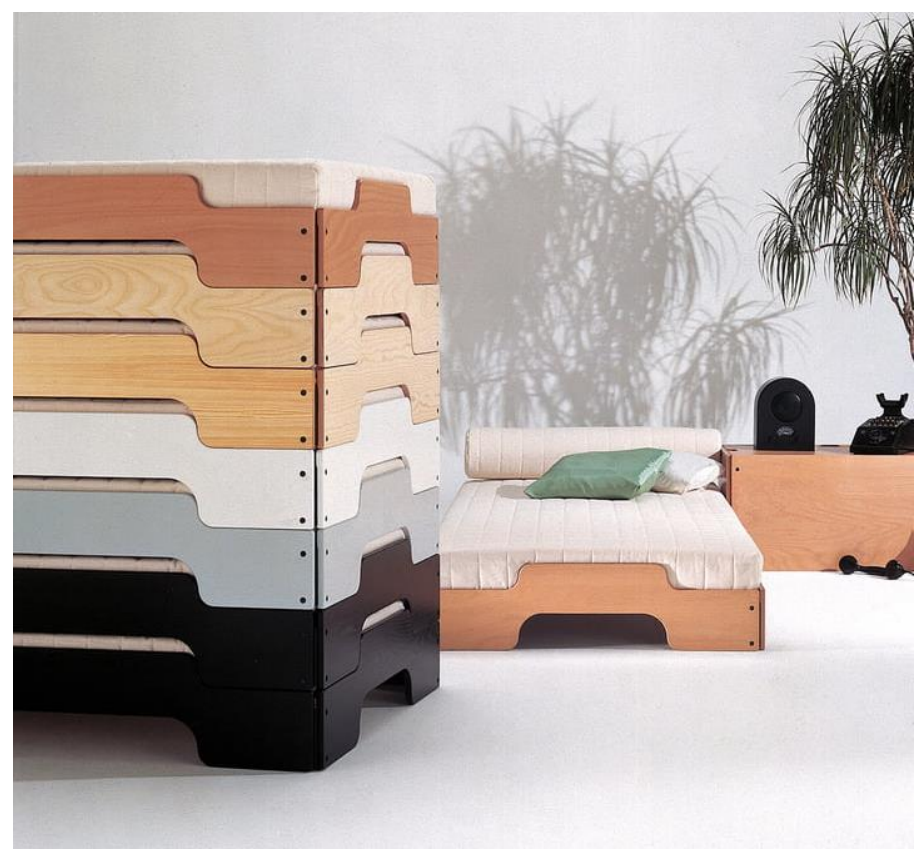

Şekil 22. Istiflenebilir yataklar(Url-19)

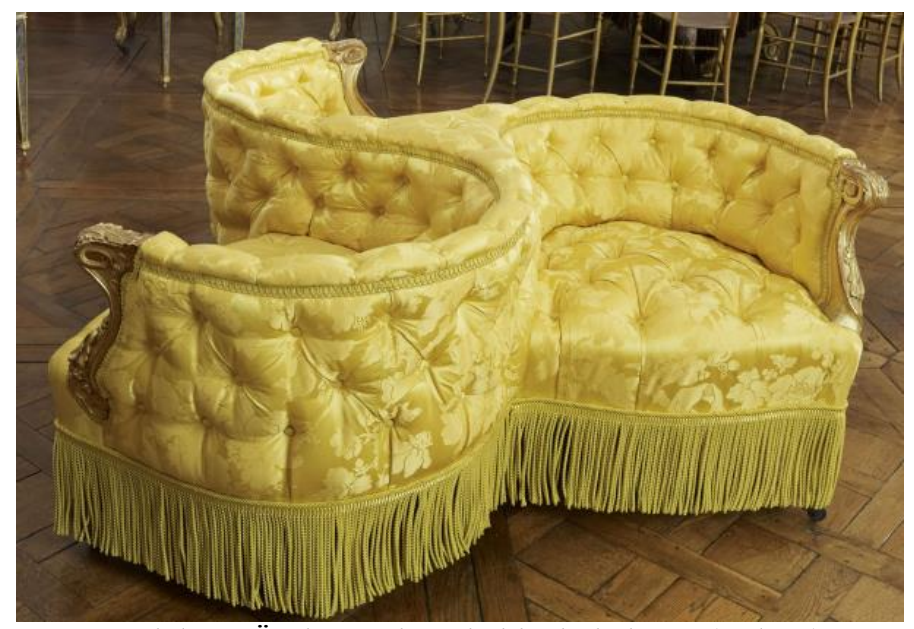

Şekil 23. Özel amaçlar: dedikodu koltuğu (Url-20)

\section{Araştırma Sonuçları ve Tartışma}

\subsection{Tasarımcı - Mobilya etkileşimi}

Mobilyalar; kim için tasarlanacak, nerede, nasıl ve ne için kullanılacak sorularının yanıtlarının oluşturulması ile biçimlenişleri ortaya çıkmakta malzeme ile ayağa kalkmakta veya giyinerek hayata geçmektelerdir. Tasarımcısının imzası niteliğini taşıyan, bir mekâna göre daha kolay algılanabilen, hızlı deneyimlenebilen ve bir etki sunabilen, bir objeye göre daha detaylı mesaj iletebilen özelliktedir.

Bir mobilya hangi döneme ait olduğu, tasarımcı, tasarlanma süreci, kişiye özel olarak veya seri üretim olduğu, kullanım alanı, tasarımcının gizlediği saklı mesajı, bulunduğu toplumun sosyo-kültürel özelliklerini, ekonomik durumunu, beğeni ve tercihlerini, alışkanlıklarını, eğitim düzeyi gibi pek çok özelliği biçiminde barındırabilmekte ve iletişim özelliği sayesinde sunabilmektedir.

Mobilyanın kullanıcısı ile buluşma aşamasındaki farklılıklar bile tasarımcısının verdiği mesajı taşıyabilmekte montajının ve taşınmasının kimin yapacağının kararı bile tasarımcının sunmak istediği etkiye bağlı olarak oluşmaktadır.

Günümüzde çok farklı biçim ve modelde mobilya üretilmektedir. Bunların arasında aynı biçimin farklı malzemelerle çağdaş üretim teknolojileri kullanılarak farklı etkilerin sunulabildiği örnekler de mevcuttur. Mobilyalar arasındaki tercih rekabetini kimliği, temsil ettiği sınıf ve sunduğu statü, markası, ilettiği mesaj veya sunduğu estetik değerler belirlemektedir.

Tasarımcısı veya kullanıcısı gözüyle her şeyde olduğu gibi mobilyanın bıraktığı ilk izlenimi, nasıl gözüktüğü veya estetik değerleri ekonomik kaygılar çerçevesinde öncelikli olarak tercihi belirlemektedir. Günümüzde ekonomik kısıtlar çerçevesinde farklı estetik ve pratik işlev özelliklerine sahip en az iki alternatif arasında kullanıcı tercihte bulunabilir aşamaya ulaşmıştır. Firmalar gerek satış pazarlama stratejileri açısından gerek doğal kaynakların sürdürülebilirliği noktasından yola çıkılarak mobilyalar üretmek amacıyla pek çok farklı yöntem ile mobilyaları kullanıcısı ile buluşturabilmektedir. Montajının ve veya nakliyesinin kullanıcıya bırakılması ile estetik açıdan yoksun olarak değerlendirilebilecek, pratik işlev açısından ise fazlasını sunarak farklı iç mekân fonksiyonlarında görev alabilen mobilyalar üretilmektedir. İşlev ve biçimlendirme bakımından kimliksiz olarak bile adlandırılabilinecek bu mobilyalar ile 
kullanıcısı arasında bir ilişki kurarak, bir anı oluşturarak, bir bağ kurabilmek mobilyanın değerini kullanıcı tarafında arttırmakta beğeni ve tercih nedeni olabilmektedir.

Günümüzde sürdürülebilirlik açısından mobilya tasarım ve üretimlerine bakıldığında; paketlenmesi ve ambalajlarındaki farklı çözüm ve malzemeler haricinde sadece geliştirilen sürdürülebilir yüzey kaplama malzemelerinin kullanıldığ görülmektedir. Atık ürünlerin geri dönüştürülemesi ile üretilen kent mobilyaları veya minik tabureler üretilebilmekte, yüzey kaplamaları ve gizli strüktür parçaları ile sürdürülebilir hale getirilmesi için çalışmalar geliştirilmektedir.

\section{Sonuç}

Bir yapı, her ne olursa olsun kullanıcısını çevre şartlarından korumak, işlevine göre hizmet sunmak ve acil bir durum anında içindekilerin o mekânı terk etmesine yetecek süreyi tanıyacak şekilde planlanmış ve oluşturulmuş ise bir mobilyada biçilen kullanım süresince seçilen malzeme ve kullanım alanına bağlı olarak sağlam ve dayanıklı olmalı, ilk günkü konforunu sunacak şekilde tasarlanmalı ve üretilmelidir.

İşlevi, malzeme seçimi, sunacağı estetik değerleri ile bir versiyonlar zinciri mobilyanın biçimlenmesinde etken oluşturmaktadır. Bu kriterlerin öncelik sıralaması kullanıcı ve tasarımcısı arasındaki iletişim ile biçimlenmekte kullanılacağı mekâna göre netleşerek oluşmaktadır.

Mobilyanın biçimlenmesi aşamasında öncelikle ana işlevin ortaya konması ile ihtiyacın ne olduğu belirlenmektedir. Sonraki aşamada estetik işlev yani beğenilen bir mobilya olması gerekliliği ortaya çıkmaktadır. Çevre ve malzeme gibi diğer faktörler hem tasarımcı hemde kullanıcı açısından biçimlendirmeyi ve tercihleri etkilemektedir. Tasarımcı yeteneği ile biçimlendirdiği, kimliğini estetik ve hatta simgesel işlevini mobilyasına yüklerken; malzeme, biçim, renk, doku gibi sembolleri kullanmaktadır. $\mathrm{Bu}$ sayede kullanıcının tercihinde öncelik kazanma çabasını yerine getirmektedir. Tasarımcı, eğitimi ve yeteneği ile bu arz talebe dayalı döngüyü, toplumun beğeni düzeyini geliştirmekte ve sanatçı sıfatına kavuşmaktadır. Tasarımlarındaki kalite artmakta ve toplumun gelişimini olumlu yönde etkileyecektir.

Sonuç olarak; Tasarımcı bir mobilyayı hayata geçirme aşamasında işlev, çevre, malzeme gibi faktörlerin yanı sıra kullanıcısı veya kullanıcı profili ile etkileşimli etmenleri de çözümlenmesi gerekmektedir. Çalışmada çözümlenmesi gereken bu başlıklar ortaya konmaya çalışılmıştır. Böylece tasarımcı için başlangıç aşamasında bir nevi yol gösterici kriterler oluşturulmuş ve kullanıcı açısından ihtiyaçların doğru belirlenmesinde kılavuzluk edebilecek ve tercih aşamasında yönlendirici olabilecek başlıklar belirlenmeye çalışılmıştır.

Tasarımcı işlevlere cevap verecek bir tasarım ortaya koymak için yola çıktığında beraberinde düşünmesi ve belirlemesi gereken başlıklar şunlardır:

- Malzeme ve yapım yöntemi

- Ölçülendirme uyum ve ağırlık

- Hiyerarşi ve statü

- Maliyet

- Toplumsal gelenek ve alışkanlıklar

- Moda ve sanat akımları

- Algi yetileri ve psikoloji

- Tasarımcı Kimliği

e-ISSN: 2148-2683
- Özel amaçlar; dönüşüm, istifleme, boyut küçültme ve depolama

$\mathrm{Bu}$ başlıklardan elde edilen veriler çerçevesinde tasarımcı mobilyasını oluşturuken; ana işleve yönelik bir tasarım ortaya koyarken Şekil 24 ve 25 'de görüleceği gibi ister tek bir kullanıcı için tasarlanan özel bir mobilya olsun ister bir markanın seri üretimi için tasarlanmış bir ürün olsun kullanıcısının beğenisine göre tercih görmekte kullanıcısı ile buluşmakata ve işlevlerini en iyi şekilde, belirlenmiş kullanım süresince, yerine getirecek şekilde üretilmektedir.

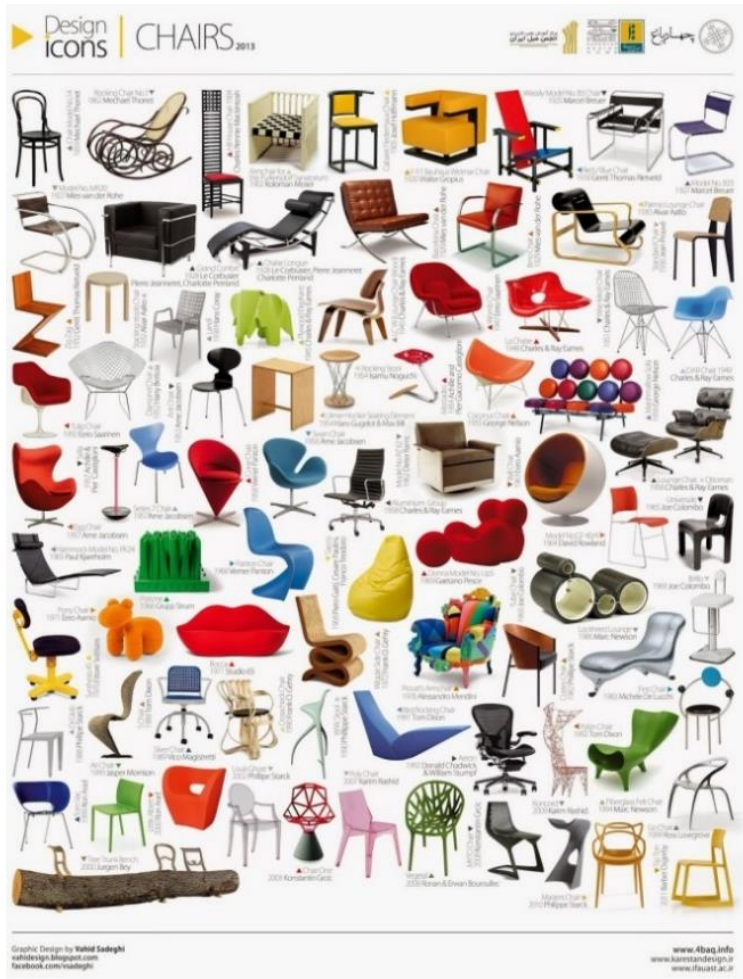

Şekil 24. Üslupların temsilcisi olmuş oturma elemanları (Url-21)

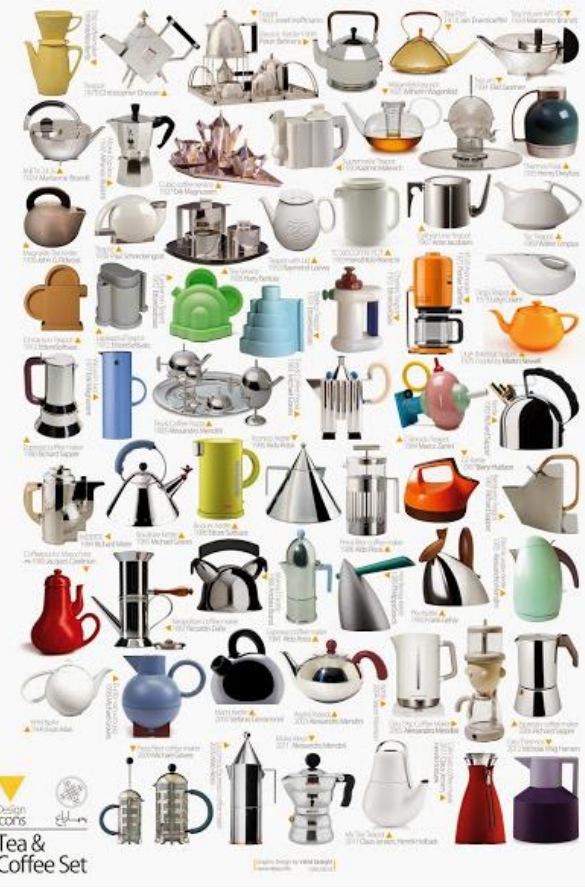

Şekil 25. Farklı kullanıcı beğenileri için üslupların temsilcisi olmuş çay kahve setleri(Url-22) 


\section{Kaynakça}

Ash, D., Brunhammer, Y., Buffet-Challié, L.,Butler, T. J., Ciechanowiecki, A., Christie, A, Coleridge, A., Grandjean, S., Handley-read, C., Harris, R. J., Hayward, H., Hillier, J., Honour, H.,Hunt, J., Huth, H., Joy, E.T.,Liversidge, J., Maszkowsak, B., Medley, M., Meister,W. P., Musgrave, C., Scheurleer, Th. H. L., Schefer, H., Smith, C. R., Thorton, P. "World Furniture", Leefung-Asco basimevi, The Hamlyn Publishing Group Limited yayınevi, ISBN NO: 0600039552, 1965, İngiltere

Baudrillard, J. 2011 Nesneler Sistemi. (O. Adanır. ve A. Karamollaoğlu, Çev.). Boğaziçi Üniversitesi Yayınevi, İstanbul

Boyla, O., 2016. Mobilya Tarihi. http://www.youblisher.com/p/589306-Mobilya-Tarihiekitaplarim-tr-gg/ (E.T.: 04.04.2016)

Hinchman, M. "History of Furniture: A Global View", 1 Eylül 2010, 1. Bask1, Fairchild Books, ISBN 13: 9781563675447 , Amerika Birleşik Devletleri.

Onur. S., 2000. "Mobilya Biçimlenmesine Etki Eden faktörler ve Tasarımcı kullanıcı faktörü üzerine bir yöntem önerisi", Sanatta Yeterlilik Tezi. İstanbul. Mimar Sinan Güzel Sanatlar Üniversitesi. Fen Bilimleri Enstitüsü

Önder, T., 1998. Dr. Öğr. Üyesi Önder Turan’a ait (Güz yarıyılı) Mobilya Tasarımı Ders Notları (Mimar Sinan Güzel Sanatlar Üniversitesi) İstanbul.

Onur, S., 2000. Dr. Öğr. Üyesi Senem Onur'a ait (Güz- Bahar yarıyılı) Mobilya Tasarımı I-II Ders Notları (Mimar Sinan Güzel Sanatlar Üniversitesi) İstanbul.

Önder, T., 1998. Dr. Öğr. Üyesi Önder Turan’a ait (Güz yarıyılı) Mobilya Tasarımı Ders Notları (Mimar Sinan Güzel Sanatlar Üniversitesi) İstanbul.

Önder, T., 1989. "Mekân Örgütlenmesi açısından MobilyaMobilya İlişkileri”. Antik\&Decor dergisi Antika, Dekorasyon Ve Sanat Dergisi, sayı:1,ss: 24-26.

Önder, T., 1989. "Tanım-Tasarım-Yapım-Tüketim açısından Mobilya \%...”. Antik\&Decor dergisi Antika, Dekorasyon Ve Sanat Dergisi, sayı:2,ss: 22-24.

Söğüt. M. A., 2004. "Oturma elemanının tasarımında strüktür ve yüzey kaplama malzemesinin biçime etkisi”, Sanatta Yeterlilik Tezi. İstanbul. Mimar Sinan Güzel Sanatlar Üniversitesi. Fen Bilimleri Enstitüsü

Suri. L., 2020. "Değişim Sürecinde Konut ve Çevre İlişkileri”. Journal of StrategicResearch in Social Science, 6(1), 51-64., Doi: 10.26579/josrss.107 (Yayın No: 6302048)

Suri. L., 2020. "Uygulama Süreci ve Uygulama Aracı Seçiminde Etkin Kriterler". Journal of Strategic Research in Social Science, 6(1), 45-62., Doi: 10.26579/jocrest.55 (Yayın No: 6302099)

Toka, C. 1978. "İnsan Araç Bağlantısında Ergonomik Tasarım İlkeleri”. Yüksek Lisans Tezi. İstanbul. İstanbul Güzel Sanatlar Akademisi. İç Mimarlık ve Endüstri Tasarımı Kürsüsü

Url-1: https:/www.thesefourwallsblog.com/interiors/new-findsmay-2019/ (E.T.: 01.05.2019)

Url-2:https://ammann-gallery.com/artist/ron-arad/(E.T.: 04.2014)

Url-3:

https://www.archiproducts.com/en/products/gufram/polyuret hane-sofa-bocca_129429 (E.T.: 04.2014)

Url-4:http://mdbarchitects.com/1880_rocking-chair-by-michaelthonet/ (E.T.:10.2013)
Url-5:https://www.architonic.com/en/product/cassinalc4/1001968 (E.T.: 29.12.2016)

Url-6:

http://www.elementa.no/archive/2016/3/11/opsvikonmovem ent (E.T.: 11.03.2016)

Url-7: https://tr.pinterest.com/pin/746260600749860733/

Url-8:https://www.trendhunter.com/trends/membrane-chair (E.T.: 08.05.2013)

Url-9:

https://minordetails.typepad.com/md_weblog/2011/05/stack sitrepeat.html (E.T.: 16.05.2011)

Url-10:https://tr.pinterest.com/pin/634233560005287963/

Url-11:https://tr.pinterest.com/pin/818529301007161418/

Url-12:

https://www.1 stdibs.com/furniture/seating/armchairs/iconicle-corbusier-jeanneret-perriand-lc2-lounge-chairs/idf $22403552 /$

Url-13:https://www.architonic.com/en/product/cassina-lc2armchair/1110473

Url-14: https:/gr.pinterest.com/pin/231442868337620675/

Url-15:https://istanbul.for91 days.com/2013/06/28/the-imperialharem-of-topkapi-palace/ (E.T.: 28.06.2013)

Url-16:https://www.pinterest.es/pin/46021227431313321/

Url-17: http://www.pontdesarts.biz/category/furniture/armchair/\#gall ery $1-19$

Url-18:http:/emlakhaber.club/tag/zaha-hadid-kimdir/(E.T.: 30.11.2018)

Url-19: https://www.connox.com/categories/furniture/beds/rolfheide-stacking-bed-coloured-lacquered.html?itm $=127010$

Url-20:https://www.messynessychic.com/2020/01/30/a-briefcompendium-of-the-conversation-chair/ (E.T.: 30.01.2020)

Url-21:https:/vahidesign.blogspot.com/2014/05/new-version-oficon-of-chairs-poster.html?m=1 (E.T.: 14.05.2014)

Url-22:https://vahidesign.blogspot.com/2014/03/tea-coffee-settimeline.html?m=1 (E.T.: 19.03.2014) 